\title{
Black silicon laser-doped selective emitter solar cell with $18.1 \%$ efficiency
}

Davidsen, Rasmus Schmidt; Li, Hongzhao; To, Alexander ; Wang, Xi; Han, Alex; An, Jack; Colwell, Jack; Chan, Catherine; Wenham, Alison; Schmidt, Michael Stenbæk

Total number of authors:

14

Published in:

Solar Energy Materials \& Solar Cells

Link to article, DOI:

10.1016/j.solmat.2015.10.018

Publication date:

2016

Document Version

Peer reviewed version

Link back to DTU Orbit

Citation (APA):

Davidsen, R. S., Li, H., To, A., Wang, X., Han, A., An, J., Colwell, J., Chan, C., Wenham, A., Schmidt, M. S., Boisen, A., Hansen, O., Wenham, S., \& Barnett, A. (2016). Black silicon laser-doped selective emitter solar cell with $18.1 \%$ efficiency. Solar Energy Materials \& Solar Cells, 144, 740-747.

https://doi.org/10.1016/j.solmat.2015.10.018

\section{General rights}

Copyright and moral rights for the publications made accessible in the public portal are retained by the authors and/or other copyright owners and it is a condition of accessing publications that users recognise and abide by the legal requirements associated with these rights.

- Users may download and print one copy of any publication from the public portal for the purpose of private study or research.

- You may not further distribute the material or use it for any profit-making activity or commercial gain

- You may freely distribute the URL identifying the publication in the public portal 


\title{
Black Silicon Laser-Doped Selective Emitter Solar Cell with $18.1 \%$ Efficiency
}

\author{
Rasmus Schmidt Davidsen ${ }^{\mathrm{a}, *}$, Hongzhao $\mathrm{Li}^{\mathrm{c}}$, Alexander $\mathrm{To}^{\mathrm{c}}$, Xi Wang ${ }^{\mathrm{c}}$, Alex \\ $\mathrm{Han}^{\mathrm{c}}$, Jack An ${ }^{\mathrm{c}}$, Jack Colwell ${ }^{\mathrm{c}}$, Catherine Chan ${ }^{\mathrm{c}}$, Alison Wenham ${ }^{\mathrm{c}}$, Michael \\ Stenbæk Schmidt ${ }^{\mathrm{a}}$, Anja Boisen ${ }^{\mathrm{a}}$, Ole Hansen ${ }^{\mathrm{a}, \mathrm{b}}$, Stuart Wenham ${ }^{\mathrm{c}}$, Allen \\ Barnett ${ }^{\mathrm{c}}$ \\ ${ }^{a}$ Department of Micro- and Nanotechnology, Technical University of Denmark (DTU) \\ ${ }^{b}$ Danish National Research Foundation's Center for Individual Nanoparticle Functionality \\ (CINF), Technical University of Denmark, DK-2800 Kgs.Lyngby, Denmark \\ ${ }^{c}$ School of Photovoltaic and Renewable Energy Engineering, UNSW Australia, Sydney 2052, \\ NSW, Australia
}

\begin{abstract}
We report fabrication of nanostructured, laser-doped selective emitter (LDSE) silicon solar cells with power conversion efficiency of $18.1 \%$ and a fill factor (FF) of $80.1 \%$. The nanostructured solar cells were realized through a single step, mask-less, scalable reactive ion etch (RIE) texturing of the surface. The selective emitter was formed by means of laser doping using a continuous wave (CW) laser and subsequent contact formation using light-induced plating of $\mathrm{Ni}$ and $\mathrm{Cu}$. The combination of RIE-texturing and a LDSE cell design has to our knowledge not been demonstrated previously. The resulting efficiency indicates a promising potential, especially considering that the cell reported in this work is the first proof-of-concept and that the fabricated cell is not fully optimized in terms of plating, emitter sheet resistance and surface passivation. Due to the scalable nature and simplicity of RIE-texturing as well as the LDSE process, we consider this specific combination a promising candidate for a cost-efficient process for future Si solar cells.
\end{abstract}

Keywords: black silicon, reactive ion etching, laser doping, LDSE, plating

\footnotetext{
*Corresponding Author, email: rasda@nanotech.dtu.dk, Ørsteds Plads building 345 East, 2800 Lyngby, Denmark, Tel.: +45 26187249
} 


\section{Introduction}

Nanoscale texturing of silicon ( $\mathrm{Si})$ surfaces has been shown [1, 2, 3, 4, 4, 5, 6, 7 ] to reduce the total weighted average optical reflectance to well below $1 \%$ over a broad range of wavelengths and incident angles. Compared to the typical front

5 surface reflectance of $\sim 2$ and $\sim 8 \%$, from conventionally textured mono- 8 and multi-crystalline [9] Si solar cells, respectively, nanoscale texturing such as described in [10, 11, 12] offers a potential of improved power conversion efficiency for Si solar cells due to reduced reflectance loss.

We use black silicon [13, 14, 11] nanostructuring to achieve low reflectance, which can be modelled in a mean-field approximation as a graded refractive index at the Si-air interface [15. von Gastrow et al. 16] reported excellent passivation of black Si surfaces using atomic layer deposition (ALD) of $\mathrm{Al}_{2} \mathrm{O}_{3}$. Repo et al. [17] achieved a power conversion efficiency of $18.7 \%$ on $400 \mu \mathrm{m}$ thick float-zone Si using cryogenic deep reactive ion etching (RIE) as texturing and plasma assisted atomic layer deposition (ALD) of $\mathrm{Al}_{2} \mathrm{O}_{3}$ for a passivated emitter rear locally diffused (PERL) cell and $22.1 \%$ on an interdigitated back contact (IBC) cell with similar ALD-passivation [18. Oh et al. 19] achieved a power conversion efficiency of $18.2 \%$ on $300 \mu \mathrm{m}$ thick float-zone Si by combining a metal-assisted wet etching black silicon process for texturing, tetramethylammonium hydroxide (TMAH) damage removal etch and thermal $\mathrm{SiO}_{2}$ passivation. Yoo et al. 20] used industry grade Czochralski (Cz) Si and RIE texturing and achieved a power conversion efficiency of $16.7 \%$. Wang et al. 21] applied black Si by metal-assisted wet etching and $\mathrm{ALD}$ of $\mathrm{Al}_{2} \mathrm{O}_{3}$ on industry grade $\mathrm{Cz} \mathrm{Si}$ and achieved $18.2 \%$ efficiency.

25 The primary reason for the relatively low efficiencies reported for black Si solar cells so far is the significant emitter and surface recombination [19, 2] resulting from increased surface area, defects from the texturing process and increased emitter doping through the nanostructured surface yielding increased Auger recombination. These effects usually lead to reduced short-circuit current and open-circuit voltage. Thus, a selective emitter design could improve the effi- 
ciency of black Si solar cells. In order to achieve a selective emitter without the use of multiple high-temperature process steps and photolithography, laser doping and subsequent self-aligned $\mathrm{Ni} / \mathrm{Cu}$-plating has been suggested by several groups [22, 23, 24]. The laser-doped selective emitter (LDSE) process offers excellent sheet resistance control, self-alignment of front metal contacts to the local highly doped areas and a fast, low-temperature process scalable to industrial throughput. Hallam et al. achieved 19.3\% efficiency for a LDSE solar cell on large-area $\mathrm{Cz}$ Si substrates using an industrial turnkey production line with the addition of laser-doping and plating 25. The LDSE process has also been successfully applied to bifacial silicon solar cells [26]. An important feature of the LDSE cell process is the replacement of screen-printed Ag front contacts with plated $\mathrm{Ni} / \mathrm{Cu}$-contacts. Due to the economic benefits of replacing $\mathrm{Ag}$ by $\mathrm{Cu}$ in the solar industry [27] and the extensive studies of Ni/Cu-plating applied for Si solar cells [28, 29, 30, 31] the self-aligned, high-performing Ni/Cu-plated 45 front contacts is an important and promising feature of LDSE solar cells. This work presents LDSE black Si solar cells fabricated on p-type $\mathrm{Cz}$ Si substrates textured by a single step, maskless RIE process. To our knowledge this combination has not been previously reported and the resulting cell is thus considered a first proof-of-concept. The emitter diffusion and surface passivation were not fully optimized, since the main goal of this study was the combination of LDSE and RIE-texturing. The primary objective of this work is to investigate how laser doping and plating processes are affected by the RIE-textured surface and vice versa. It is not obvious how a differently textured surface affects e.g. electrical properties of the laser doped regions and subsequent plating. material. Thus a different emitter profile may change the defect generation and risk of Schottky contact formation. Besides laser doping and plating, several process steps could be affected by changing from conventional to RIE-texturing: Emitter diffusion could change with effective surface area and deposition of antireflective coating may not yield the expected layer thickness and uniformity due to the nanostructured front surface. Such effects could then further affect the 
subsequent laser doping and plating processes. An example hereof is spurious plating on the surface in case of pinholes in the dielectric coating resulting from the different surface topology. solar cells.

\section{Approach}

The maskless RIE process presented in this work is applied as the texturing step in the following solar cell fabrication process:

- Saw damage removal by etching in $30 \% \mathrm{KOH}$ at $75^{\circ} \mathrm{C}$ for 2 minutes and subsequent cleaning in $20 \% \mathrm{HCl}$ at room temperature for 5 minutes and rinsing in deionized water.

- Texturing using maskless RIE at room temperature in a $\mathrm{O}_{2}$ and $\mathrm{SF}_{6}$ plasma with a gas flow ratio of $\mathrm{O}_{2}: \mathrm{SF}_{6}=1: 1$, chamber pressure of 24 mTorr, $13.56 \mathrm{MHz}$ radio-frequency platen power of $100 \mathrm{~W}$ using a SPTS RIE system.

- Emitter formation using a tube furnace from Tempress Systems with liquid $\mathrm{POCl}_{3}$ as dopant source at a temperature of $840{ }^{\circ} \mathrm{C}$ and atmospheric pressure for 50 min in $\mathrm{O}_{2}$ and $\mathrm{N}_{2}$ ambient, followed by removal of phosphorsilicate glass (PSG) in $5 \%$ hydrofluoric acid (HF).

- Plasma enhanced chemical vapour deposition (PECVD) of $75 \mathrm{~nm}$ hydrogenated amorphous silicon nitride $\left(\mathrm{SiN}_{x}: \mathrm{H}\right)$ anti-reflective coating at $400{ }^{\circ} \mathrm{C}$ using a Roth \& Rau MAiA tool.

- Screen-printing of $\mathrm{Al}$ rear contact with standard $\mathrm{Al}$ paste, which was fired using a Sierra Therm infra-red fast-firing furnace, with a peak temperature set point of $835^{\circ} \mathrm{C}$ and a belt speed of $4500 \mathrm{~mm} / \mathrm{min}$. 
- Laser doping of the front surface using spin-on of $85 \%$ phosphoric acid as doping source followed by laser doping using a continuous wave laser at a wavelength of $532 \mathrm{~nm}, 20 \mathrm{~W}$ laser power and 2-4 m/s laser scan speed. quent $\mathrm{Cu}$ plating

- Ni sintering using rapid thermal processing (RTP) in $\mathrm{N}_{2}$ ambient at $350{ }^{\circ} \mathrm{C}$ for 2 minutes

- Light-induced plating of $\mathrm{Cu}$ onto the $\mathrm{Ni}$ seed layer

- Edge isolation by laser ablation using a $20 \mathrm{~W}$ Nd:YAG Lee laser tool.

The starting substrates were $25 \times 25 \mathrm{~mm}^{2}$ p-type, $\mathrm{CZ}$ mono-crystalline $\mathrm{Si}$ with a thickness of $200 \mu \mathrm{m}$ and a resistivity of $1-3 \Omega \mathrm{cm}$.

Figure 1 shows a schematic cross-section of the fabricated solar cell.

\section{Characterization}

$\mathrm{J}-\mathrm{V}$ curves and photovoltaic performance including short-circuit current density, $J_{\mathrm{SC}}$, open-circuit voltage, $V_{\mathrm{OC}}$, fill factor, $\mathrm{FF}$, and power conversion efficiency were measured on complete cells under 1 sun illumination $\left(1000 \mathrm{~W} / \mathrm{m}^{2}\right.$, AM1.5G) using a ELH halogen light source, Advantest TR6143 DC Source Mea-

surement Unit and Labview software for data collection. The illumination was calibrated using the known short-circuit current of a reference mono-crystalline Si screen-printed solar cell.

A LEO 1550 Scanning Electron Microscope (SEM) was used to characterize the nanostructured surface topology.

10 Suns- $V_{\mathrm{OC}}[32$, 33] measurements were performed using a Sinton WCT-120 Lifetime tester. The $J_{\mathrm{SC}}$ value from the IV-measurement was used.

Reflectance was measured using a Perkin Elmer integrating sphere and spectrometer. The absorptance was measured using a center mount sample holder 
inside the integrating sphere.

External Quantum Efficiency (EQE) was measured without bias light using a PV Measurement QE system and Internal Quantum Efficiency (IQE) was calculated based on the EQE and reflectance measurements.

Photoluminescence (PL) 34] was measured at open-circuit conditions using a BTi luminescence imaging tool.

${ }_{120}$ Cross-sectional Focused Ion Beam (FIB)/SEM images of the plated Ni/Cu front contacts were taken using a Helios Nanolab 600 tool from FEI.

\section{Results}

Figure 2 shows a SEM image of the RIE-textured Si surface at $40^{\circ}$ tilt before any further processing. The nanostructures have a height of $\sim 300-500 \mathrm{~nm}$ and a distance between the structures of $\sim 300-500 \mathrm{~nm}$. The nanostructures are conical-like hillocks randomly distributed across the entire solar cell surface.

Figure 3 shows the total light absorptance of the RIE-textured Si wafer before any further processing as function of wavelength. The absorptance was measured using a centre-mount sample holder placed inside the integrating sphere.

The incident angle of the light source deviated $8^{\circ}$ from normal incidence due to the geometry of the measurement setup. The absorptance is $\sim 99 \%$ in most of the solar spectrum up to a wavelength of $\sim 1000 \mathrm{~nm}$, at which the light starts to transmit through the $200 \mu \mathrm{m}$ thick Si wafer. The integrated average absorptance is $99.2 \%$ in the wavelength range $300-900 \mathrm{~nm}$ and decreases to $91.7 \%$ from 900 to $1000 \mathrm{~nm}$. The calculated absorptance of a $200 \mu \mathrm{m}$ Si wafer without any texturing but with an assumed reflectance of $0 \%$ is plotted for comparison. Also, the simulated absorptance of a $200 \mu \mathrm{m}$ Si wafer textured with upright random pyramids with $75 \mathrm{~nm} \mathrm{SiN}_{x}: \mathrm{H}$ AR-coating is shown for comparison. It is seen that RIE-texturing results in increased absorptance of wavelengths above 1000 $\mathrm{nm}$ compared to non-textured Si and similar absorptance of wavelengths above $1000 \mathrm{~nm}$ compared to conventionally textured mono-crystalline Si solar cells. This indicates some path-length enhancement of longer wavelengths within the 
RIE-textured wafer. Based on the absorption coefficient of Si the path-length enhancement of RIE-textured $\mathrm{Si}$ is estimated to 20 times at a wavelength of $1100 \mathrm{~nm}$.

The fabricated RIE-textured LDSE solar cells were characterized under 1 sun illumination (1000 W/m², AM1.5G). Figure 4 shows the measured J-V curve of the best black Si LDSE cell at 1 sun. The short-circuit current density, $J_{\mathrm{SC}}$, is $36.3 \mathrm{~mA} / \mathrm{cm}^{2}$ and open-circuit voltage, $V_{\mathrm{OC}}$, is $624 \mathrm{mV}$. The power conversion efficiency is $18.1 \%$ and the fill factor, $\mathrm{FF}$, is $80.1 \%$. The pseudo light $\mathrm{J}-\mathrm{V}$ curve and Suns- $V_{\mathrm{OC}}$ measurement seen in Figure 5 shows that the best black $\mathrm{Si}$ LDSE cell has a pseudo fill factor, $\mathrm{pFF}$, of $82.3 \%$ and a pseudo power conversion efficiency, pEff, of $18.7 \%$ without the effect of series resistance. The high $\mathrm{pFF}$ indicates that shunting is low and the pseudo efficiency indicates that se155 ries resistance accounts for $\sim 0.6 \%$ point efficiency loss compared to the actual power conversion efficiency. The linearly increasing relationship between the illumination and $V_{\mathrm{OC}}$ seen in the bottom part of Figure 5 indicates that neither shunting nor Schottky contacts are significant for the best black Si LDSE cell. This is encouraging considering the effect texturing may have on laser doping and plating processes, which could lead to increased defect generation. This does not seem to be the case from the Suns- $V_{\mathrm{OC}}$ measurement. The increase in $V_{\mathrm{OC}}$ for intensities of 6-7 suns compared to the double diode model may be due to saturation of the surface recombination, which dominates the cell performance at 1 sun.

${ }_{165}$ Table 1 shows measured $J_{\mathrm{SC}}, V_{\mathrm{OC}}$, power conversion efficiency and FF for three different RIE-textured LDSE solar cells processed at three different laser speeds. The results in Table 1 show that the three RIE-textured LDSE solar cells have efficiencies in the range $17.5-18.1 \%$. The differences are primarily due to differences in FF. The different fill factors may be explained by the different laser 170 speeds according to the result in Figure 6, which shows Suns- $V_{\mathrm{OC}}$ at low injection for the three RIE-textured LDSE cells with different laser speeds. Figure 6 shows that a laser speed of $3 \mathrm{~m} / \mathrm{s}$ leads to the highest open circuit voltage at low injection and an almost linear relationship between $V_{\mathrm{OC}}$ and illumination 
intensity. The cell processed at a laser speed of $2 \mathrm{~m} / \mathrm{s}$ has significantly lower $V_{\mathrm{OC}}$ at low injection and a less linear relationship between $V_{\mathrm{OC}}$ and intensity. This is also reflected in the lower $\mathrm{pFF}$ of this particular sample.

After $\mathrm{Ni} / \mathrm{Cu}$-plating it was clear that significant spurious plating had occurred and that the surface had local scratches and pinholes through the dielectric, in which $\mathrm{Ni}$ and $\mathrm{Cu}$ has plated unintentionally. The top part of Figure 7 shows photographs of the finished cells where the plating defects are visible. The bottom part of Figure 7 shows a SEM-image of the RIE-textured surface of the final cells, where an example of the spuriously plated $\mathrm{Ni} / \mathrm{Cu}$ is also visible. In order to investigate the lines defined by the laser, optical microscope images were taken. The top image in Figure 8 shows an optical microscope image of laser-doped lines on the RIE-textured Si surface. The image was taken at the point where a metal finger intersects the busbar. The laser-scribed lines are approximately $20 \mu \mathrm{m}$ wide with $\sim 5 \mu \mathrm{m}$ laser damage on each side of the lines. Note that each busbar consists of 10 separate lines about $20 \mu \mathrm{m}$ wide, spaced $\sim 80 \mu \mathrm{m}$ apart and metallized in the same light-induced plating process as the fingers. The middle image of Figure 8 shows an optical microscope image of the $\mathrm{Ni} / \mathrm{Cu}$-plated metal lines in this case from the busbar lines. It is seen that the plated contacts are between 18 and $28 \mu \mathrm{m}$ wide. The total contact fraction is $\sim 2.5 \%$ of the total cell area assuming $23 \mu \mathrm{m}$ wide fingers. The bottom image in Figure 8 shows a top-view SEM-image of a Ni/Cu-plated line. In the SEM-image an example of spurious metal plating is also seen.

Figure 9 shows a SEM-image of the cross-section of a laser-doped line plated with Ni/Cu. The cross-section was defined by a Focused Ion Beam (FIB). The plated metal line is $\sim 30 \mu \mathrm{m}$ wide and $\sim 10 \mu \mathrm{m}$ in height. The layer on top of the $\mathrm{Ni} / \mathrm{Cu}$-line is $\mathrm{Pt}$ used solely for sample protection during FIB cutting. Note that the black silicon nanostructures can be seen on the sides of the laser-doped line. The nanostructures are not seen in the laser-doped region in the center of the plated Si region, since the $\mathrm{Si}$ in this region has been melted and re-solidified during the laser doping process.

Figure 10 shows EQE and IQE of the complete $18.1 \%$ cell and total reflectance 

expected short-circuit current density $36.5 \mathrm{~mA} / \mathrm{cm}^{2}$ which is in almost perfect agreement with the $36.3 \mathrm{~mA} / \mathrm{cm}^{2}$ that was measured.

Figure 11 shows the total reflectance of the RIE-textured surface with ARcoating before and after $\mathrm{Ni} / \mathrm{Cu}$-plating, respectively, as function of wavelength. plating seen in Figure 7. The beam spot size of the light source was $\sim 2 \mathrm{~cm}$ in diameter and covered the majority of the cell area including the busbar and 
metal fingers.

235 Figure 12 shows an open-circuit photoluminescence (PL) image of the $18.1 \%$ cell after Ni plating and sintering. The PL-image shows increased recombination at the laser-doped, Ni-plated busbar and fingers, which is expected for Si-metal interfaces. Furthermore, circular points or agglomerations of lower PL-signal intensity can be seen all over the surface. This indicates that the firing temperature used after rear $\mathrm{Al}$ screen-printing was slightly too high for the particular samples, leading to a non-uniform back-surface field.

\section{Discussion}

The power conversion efficiency of $18.1 \%$ of the black Si LDSE cell fabricated in this work is comparable to the best efficiencies reported for front-contacted black Si solar cells [17, 19, 21]. Table 2 shows selected cell results reported for black Si solar cells [11]. From Table 2 it appears that the cell in this work has superior fill factor compared to existing black silicon cells, while $\mathrm{J}_{\mathrm{SC}}$ and $\mathrm{V}_{\mathrm{OC}}$ are on par or slightly reduced compared to [17]. The lack of improvement to $\mathrm{J}_{\mathrm{SC}}$ and $\mathrm{V}_{\mathrm{OC}}$ may be explained by the unintentionally too heavily doped emitter, inadequate surface passivation and the unintentional spurious plating; optimized processing is thus expected to improve both key parameters significantly. The very high fill factor on the other hand is due to a near optimum laser power and scan speed used during laser doping of the best device, resulting in very low contact resistance. We note that the optimum laser doping conditions are different from those on planar silicon probably due to stronger coupling of the laser power into the structure.

In general, this result is encouraging considering that industrial grade $\mathrm{Cz} \mathrm{Si}$ wafers were used and that the complete cells in this work were not fully optimized:

First of all the cells had significant spurious plating as shown in Figure 7. This induces a direct loss of current, since the reflectance of the complete cells is 
significantly higher than a similar cell without spurious plating. The reflectance difference is shown in Figure 11 and the additional integrated average reflectance in the range 300-1000 nm attributed only to spurious plating can be estimated by the following considerations: The integrated average reflectance in the range $300-1000 \mathrm{~nm}$ is $1.20 \%$ before plating and $6.38 \%$ after plating. The front contact grid only covers $\sim 2.5 \%$ of the cell area assuming $23 \mu \mathrm{m}$ wide fingers. Based on the metal grid coverage the grid itself only accounts for additional reflectance of $270 \sim 1.23 \%$ assuming $50 \%$ reflectance of $\mathrm{Cu}$ in the wavelength range $300-1000 \mathrm{~nm}$. The spurious plating must account for the difference between the additional reflectance after plating and reflectance from the grid. Thus the spurious plating accounts for $\sim 3.95 \%$. This is a direct reflection loss, which can be at least partly avoided by minimizing spurious plating. Furthermore, spurious plating 275 in scratches such as seen in Figure 7 is likely to cause increased surface recombination, since the plated metal contacts directly to a lightly doped emitter, which shields minority carriers less than a heavily doped emitter, thus causing enhanced recombination at the metal-Si interface. It is however encouraging that the Suns- $V_{\mathrm{OC}}$ measurement in Figure 5 does not indicate any increased defect generation or Schottky contact formation.

The Suns- $V_{\mathrm{OC}}$ result in Figure 6 indicates the relationship between laser speed and pseudo FF. From the result in Figure 6 it seems that $3 \mathrm{~m} / \mathrm{s}$ leads to the most ideal performance, ultimately leading to a higher FF and power conversion efficiency than the cells processed at 2 and $4 \mathrm{~m} / \mathrm{s}$, respectively. The lower ${ }_{285} V_{\mathrm{OC}}$ at low injection for the cell processed at $2 \mathrm{~m} / \mathrm{s}$ may be due to increased laser damage at the slower scan speed leading to increased Shockley-Read-Hall recombination in the laser doped regions. The pseudo FF of the cell processed at $4 \mathrm{~m} / \mathrm{s}$ is almost as high as for $3 \mathrm{~m} / \mathrm{s}$. However, the FF is still significantly lower, which indicates that the problem for this cell is rather series resistance. This may be due to a lighter doping caused by the faster scan speed. Thus, it seems that a laser speed of $3 \mathrm{~m} / \mathrm{s}$ is close to the optimal compromise between minimized laser damage and minimized series resistance for RIE-textured laserdoped solar cells. 
Assuming that the spurious plating is due to pinholes and other non-uniformities in the dielectric AR-coating, the problem could be minimized by increasing the thickness of the $\mathrm{SiN}_{x}: \mathrm{H}$ layer. The layer may be even thinner than expected, because the deposition rate in the PECVD process may not be the same for RIE-textured Si compared to conventionally textured Si. Even a non-uniform layer would not induce spurious plating as long as the dielectric layer is completely covering the Si surface with sufficient thickness to completely isolate the surface from the plating electrolyte. It is assumed that the pretreatment using hydrofluoric acid ( $\mathrm{HF}$ ) immediately prior to Ni plating further increases the risk of pinholes, since the $\mathrm{SiN}_{x}: \mathrm{H}$ coating is etched by $\mathrm{HF}$ to some degree. A negative effect of increasing the $\mathrm{SiN}_{x}: \mathrm{H}$ thickness could be increased reflectance and absorption in the AR-coating. However, the AR-properties of the $\mathrm{SiN}_{x}: \mathrm{H}$ coating are less critical on RIE-textured $\mathrm{Si}$, due to the very low reflectance from the black Si surface itself. The increased absorption in the AR-coating could be minimized by adjusting the layer thickness and the HF process in order to minimize pinholes, while maintaining an acceptably low absorption in the ARcoating.

The phosphorus emitter was too heavily doped resulting in a sheet resistance of $40 \Omega$ measured with a 4-point probe after phosphorus diffusion. This was unintentional, since the full area sheet resistance of such selective emitter should ideally be on the order of $100 \Omega$, which was also measured on planar Si reference wafers from the same diffusion process. This suggests that the decreased sheet resistance is due to faster diffusion of dopant atoms through the nanostructured Si surface. By decreasing time and temperature of the diffusion process, we expect to improve the emitter in future studies. From the QE measurement seen in Figure 10 a significant decrease in EQE and IQE is seen for wavelengths below $320600 \mathrm{~nm}$. This indicates significant emitter and surface recombination, which is expected from black Si, if the surface is not well passivated. Since a standard $\mathrm{SiN}_{x}: \mathrm{H}$ AR-coating was used as the only passivation layer on these cells, it is expected that the short wavelength response can be significantly improved in future studies by optimizing the $\mathrm{SiN}_{x}: \mathrm{H}$ coating or by applying different dielec- 
From the PL-image in Figure 12 small circular structures with slightly lower PL-signal can be seen. We suggest that this is due to a too high firing temperature used for rear $\mathrm{Al}$ screen-printing on these particular samples. We expect this to be improved in future studies.

330 By combining the potential improvements mentioned above significantly higher power conversion efficiency of this new kind of cell structure is expected. This will be investigated in future studies.

\section{Conclusion}

$\mathrm{Ni} / \mathrm{Cu}$-plated black Si LDSE solar cells have been fabricated on industrial best cell has a power conversion efficiency of $18.1 \%$ with a fill factor of 80.1 $\%$. Since the cell was not optimized in terms of spurious plating, emitter sheet resistance and surface passivation, it is expected that the efficiency of black $\mathrm{Si}$ LDSE cells will be significantly higher in the near future. To our knowledge this 340 is the first RIE-textured LDSE cell reported and we therefore consider this a proof-of-concept.

\section{Acknowledgements}

The funding support for this work from the Australian Renewable Energy Agency (ARENA) is gratefully acknowledged. Center for Individual Nanoparticle Functionality (CINF) is sponsored by The Danish National Research Foundation (DNRF 54). The authors would like to thank Mattias Juhl for assistance with absorptance measurements. The authors would also like to thank Brett Hallam, Malcolm Abbott and Craig Johnson for advice on process flow and cell design. 
[1] Priolo, F., Gregorkiewicz, T., Galli, M., Krauss, T.F., Silicon nanostructures for photonics and photovoltaics, Nature Nanotechnology 9 19-32 (2014) DOI: 10.1038/NNANO.2013.271.

[2] Davidsen, R.S., Nordseth, Ø., Boisen, A., Schmidt, M.S., Hansen, O., "Plasma texturing on large-area industrial grade CZ silicon solar cells", 28th EU PVSEC Conference Proceedings (2013).

[3] Zhu, J., Yu, Z., Fan, S., Cui, Y., "Nanostructured photon management for high performance solar cells", Materials Science and Engineering R 70 $330340(2010)$

[4] Nguyen, K.N., Abi-Saab, D., Basset, P., Richalot, E., Marty, F., Angelescu, D., Leprince-Wang, Y., Bourouina, T., "Black silicon with sub-percent reflectivity: Influence of the 3D texturization geometry", Solid-State Sensors, Actuators and Microsystems Conference (Transducers), 16th International Transducers 11 354-357 (2011).

365 [5] Kelzenberg, M.D., Boettcher, S.W., Petykiewicz, J.A., Turner-Evans, D.B., Putnam, M.C., Warren, E.L., Spurgeon, J.M., Briggs, R.M., Lewis, N.S., Atwater, H.A., "Enhanced absorption and carrier collection in Si wire arrays for photovoltaic applications", Nature Materials 9239244 (2010), DOI: 10.1038/NMAT2635.

[6] Huang, Y-F., Chattopadhyay, S., Jen, Y-J., Peng, C-Y., Liu, T-A., Hsu, Y-K., Pan, C-L., Lo, H-C., Hsu, C-H., Chang, Y-H., Lee, C-S., Chen, K-H., Chen, L-C., "Improved broadband and quasiomnidirectional anti-reflection properties with biomimetic silicon nanostructures", Nature Nanotechnology 2770 - 774 (2007).

375 [7] Parretta, A., Sarno, A., Tortora, P., Yakubu, H., Maddalena, P., Zhao, J., Wang, A., "Angle-dependent reflectance measurements on photovoltaic materials and solar cells", Optics Communications 172 139-151 (1999). 
[8] Zhao, L., Zuo, Y.H., Zhou, C.L., Li, H.L., Diao, H.W., Wang, W.J., "Theoretical investigation on the absorption enhancement of the crystalline silicon solar cells by pyramid texture coated with SiNx:H layer", Solar Energy $\mathbf{8 5}$ $530-537$ (2011).

[9] Macdonald, D., Cuevas, A., Kerr, M., Samundsett, C., Ruby, D., Winderbaum, S., Leo, A., "Texturing Industrial Multicrystalline Silicon Solar Cells", Solar Energy 76 No.1 277-283 (2004)

[10] Rahman, A., Ashraf,A., Xin, H., Tong, X., Sutter, P., Eisaman, M.D., Black, C.T., "Sub-50-nm self-assembled nanotextures for enhanced broadband antireflection in silicon solar cells", Nature Communications 6, 5963 (2015), DOI: $10.1038 /$ ncomms6963.

[11] Liu, X., Coxon, P.R., Peters, M., Hoex, B., Cole, J.M., Fray, D.J., "Black Silicon: Fabrication methods, properties, and solar energy applications", Review Article, Energy \& Environmental Science, Royal Society of Chemistry 7 3223-3263 (2014) DOI: 10.1039/c4ee01152j.

[12] Allen, T., Bullock, J., Cuevas, A., Baker-Finch, S., Karouta, F. "Reactive ion etched black silicon texturing: A comparative study", In Photovoltaic Specialist Conference (PVSC), IEEE 40th, pp. 0562-0566, IEEE (2014), doi:10.1109/PVSC.2014.6924983

[13] Her, T.H., Finlay, R.J., Wu, C., Deliwala, S., Mazur, E., "Microstructuring of silicon with femtosecond laser pulses", Appl. Phys. Lett. 73 1673-1675 (1998).

[14] Jansen, H., Deboer, M., Legtenberg, R., Elwenspoek, M., "The Black Silicon Method - a Universal Method for Determining the Parameter Setting of a Fluorine-Based Reactive Ion Etcher in Deep Silicon Trench Etching with Profile Control", Journal of Micromechanics and Microengineering 5 115-120 (1995). 
[20] Yoo, J., "Reactive ion etching (RIE) technique for application in crystalline silicon solar cells", Solar Energy 84 730-734 (2010).

[21] Wang, W-C., Lin, C-W., Chen, H-J., Chang, C-W., Huang, J-J., Yang, MJ., Tjahjono, B., Huang, J-J., Hsu, W-C., Chen, M-J., "Surface Passivation

[15] Stephens, R.B., Cody, G.D., "Optical Reflectance and Transmission of a Textured Surface", Thin Solid Films 45 19-29 (1977).

[16] von Gastrow, G., Alcubilla, R., Ortega, P., Yli-Koski, M., Conesa-Boj, S., i Morral, A. F., Savin, H., "Analysis of the Atomic Layer Deposited Al2O3 field-effect passivation in black silicon", Solar Energy Materials and Solar Cells 142, 29-33 (2015), doi:10.1016/j.solmat.2015.05.027

[17] Repo, P., Benick, J., Vähänissi, V., Schön, J., von Gastrow, G., Steinhauser, B., Schubert, M.C., Hermle, M., Savin, H., "N-type black silicon solar cells", SiliconPV, Energy Procedia 38 866-871 (2013).

[18] Savin, H., Repo, P., von Gastrow, G., Ortega, P., Calle, E., Garn, M., Alcubilla, R., "Black silicon solar cells with interdigitated back-contacts achieve 22.1\% efficiency", Nature nanotechnology 10624628 (2015), doi: 10.1038/NNANO.2015.89

[19] Oh, J., Yuan, H.C., Branz, H., "An 18.2 \%-efficient black-silicon solar cell achieved through control of carrier recombination in nanostructures", Nature Nanotechnology 7 743-748 (2012).

of Efficient Nanotextured Black Silicon Solar Cells Using Thermal Atomic Layer Deposition", ACS Appl. Mater. Interfaces 597529759 (2013) DOI: dx.doi.org/10.1021/am402889k

[22] Kyeong, D., Cho, S-H., Lim, J-K., Lee, K., Hwang, M-I., Lee, W-J., Cho, E.C., "Approaching 20\%-efficient selective-emitter solar cells with copper front contacts on industrial $156 \mathrm{~mm}$ CZ Si wafers", Proceedings, 27th European Photovoltaic Solar Energy Conference and Exhibition (2012) 
[23] Hallam, B., Uruea, A., Russell, R., Aleman, M., Abbott, M., Dang, C., Wenham, S., Tous, L., Poortmans, J., "Efficiency enhancement of i-PERC solar cells by implementation of a laser doped selective emitter", Solar Energy Materials \& Solar Cells 134 89-98 (2015)

[24] Tousa, L., Russella, R., Dasa, J., Labiea, R., Ngamoc, M., Horzela, J., Philipsena, H., Sniekersb, J., Vandermissena, K., van den Brekeld, L., Janssensa, T., Alemana, M., van Dorpa, D.H., Poortmansa, J., Mertens, R., "Large area copper plated silicon solar cell exceeding 19.5\% efficiency", 3rd Workshop on Metallization for Crystalline Silicon Solar cells (2011)

[25] Hallam, B., Wenham, S., Sugianto, A., Mai, L., Chong, C., Edwards, M., Jordan, D., Fath, P., "Record Large-Area p-Type CZ Production Cell Efficiency of 19.3\% Based on LDSE Technology", IEEE Journal of Photovoltaics 1 No. 1 43-48 (2011)

[26] Wang, X., Allen, V., Vais, V., Zhao, Y., Tjahjono, B., Yao, Y., Wenham, S., Lennon, A., "Laser-doped metal-plated bifacial silicon solar cells", Solar Energy Materials \& Solar Cells 131 37-45 (2014)

[27] Green, M.A., "Silicon solar cells: State-of-the-art", Phil. Trans. R. Soc. A 371 (2013), DOI: dx.doi.org/10.1098/rsta.2011.0413

[28] Flynn, S., Lennon, A., "Copper penetration in laser-doped selective-emitter silicon solar cells with plated nickel barrier layers", Solar Energy Materials \& Solar Cells 130309316 (2014)

[29] Rehman, A.u., Lee, S.H., "Review of the Potential of the Ni/Cu Plating Technique for Crystalline Silicon Solar Cells", Materials 7 1318-1341 (2014), DOI:10.3390/ma7021318

[30] Geisler, C., Hördt, W., Kluska, S., Mondon, A., Hopman, S., Glatthaar, M., "Overcoming electrical and mechanical challenges of continuous wave laser processing for $\mathrm{NiCu}$ plated solar cells", Solar Energy Materials \& Solar Cells 1334855 (2015) 
[31] Su Zhou, Chunlan Zhou, Wenjing Wang, Junjie Zhu, Yehua Tang, Jingwei Chen, Yan Zhao, "Comprehensive study of light induced plating of nickel and its effect on large area laser doped crystalline solar cells" Solar Energy Materials \& Solar Cells 1253338 (2014)

[32] Sinton, R. A., A. Cuevas, "A quasi-steady-state open-circuit voltage method for solar cell characterization" 16th European Photovoltaic Solar Energy Conference 25 1152-1155 (2000).

[33] Trupke, T., Bardos, R. A., Abbott, M. D., Cotter, J. E., "Sunsphotoluminescence: Contactless determination of current-voltage characteristics of silicon wafers" Applied Physics Letters, 87 9, 093503 (2005)

470 [34] Trupke, T., Bardos, R. A., Schubert, M. C., Warta, W."Photoluminescence imaging of silicon wafers", Applied Physics Letters, 89 4, 044107 (2006) 


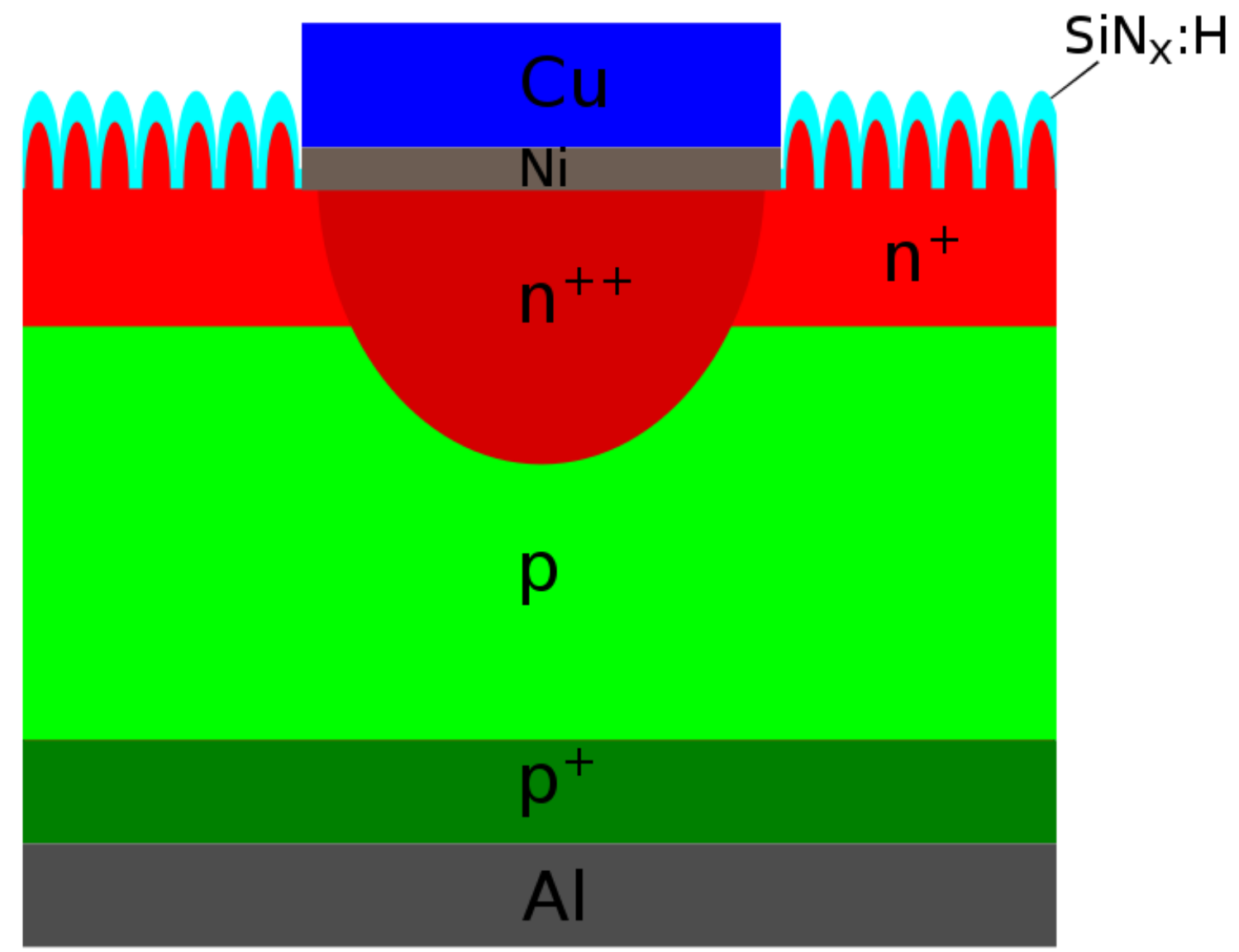

Figure 1: Sketch of the black Si LDSE solar cell structure. The cells are textured in a singlestep, maskless RIE process. The highly doped regions of the selective emitter is formed by means of local laser doping using phosphoric acid dopant and a continuous wave laser. The rear contact is screen-printed and fired $\mathrm{Al}$ and the front contacts are plated $\mathrm{Ni} / \mathrm{Cu}$. The dimensions of the different layers are not to scale. 


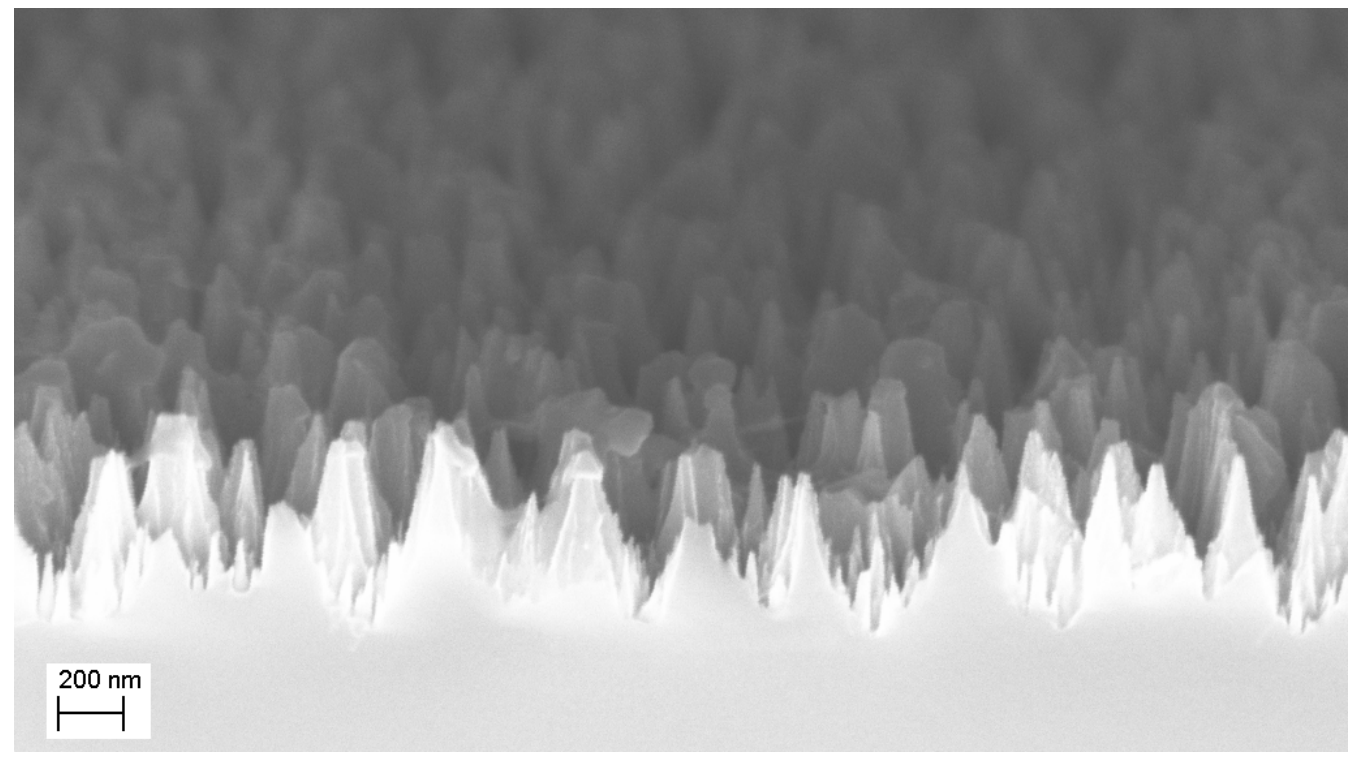

Figure 2: SEM-image at $40^{\circ}$ tilt of the RIE-textured Si surface before any further processing. The nanostructures have a height of $\sim 300-500 \mathrm{~nm}$ and a distance between the structures of $\sim 300-500 \mathrm{~nm}$. The nanostructures are conical-like hillocks randomly distributed across the entire solar cell surface.

\begin{tabular}{lrrrrr}
\hline Laser Speed & Efficiency [\%] & $\mathrm{J}_{\mathrm{SC}}\left[\mathrm{mA} / \mathrm{cm}^{2}\right]$ & $\mathrm{V}_{\mathrm{OC}}[\mathrm{V}]$ & $\mathrm{FF}[\%]$ & $\mathrm{pFF}[\%]$ \\
\hline $2 \mathrm{~m} / \mathrm{s}$ & 17.5 & 36.0 & 0.624 & 77.9 & 81.0 \\
$3 \mathrm{~m} / \mathrm{s}$ & 18.1 & 36.3 & 0.624 & 80.1 & 82.3 \\
$4 \mathrm{~m} / \mathrm{s}$ & 17.5 & 35.8 & 0.624 & 78.4 & 82.0 \\
\hline
\end{tabular}

Table 1: Power conversion efficiency, short-circuit current density, open-circuit voltage and fill factor at 1 sun illumination $\left(1000 \mathrm{~W} / \mathrm{m}^{2}\right.$, AM1.5G) of conventionally and RIE-textured LDSE Si cells with laser speeds of 2, 3 and $4 \mathrm{~m} / \mathrm{s}$, respectively. Furthermore, the pseudo fill factor, $\mathrm{pFF}$, determined by Suns- $\mathrm{V}_{\mathrm{OC}}$ measurements is given. 


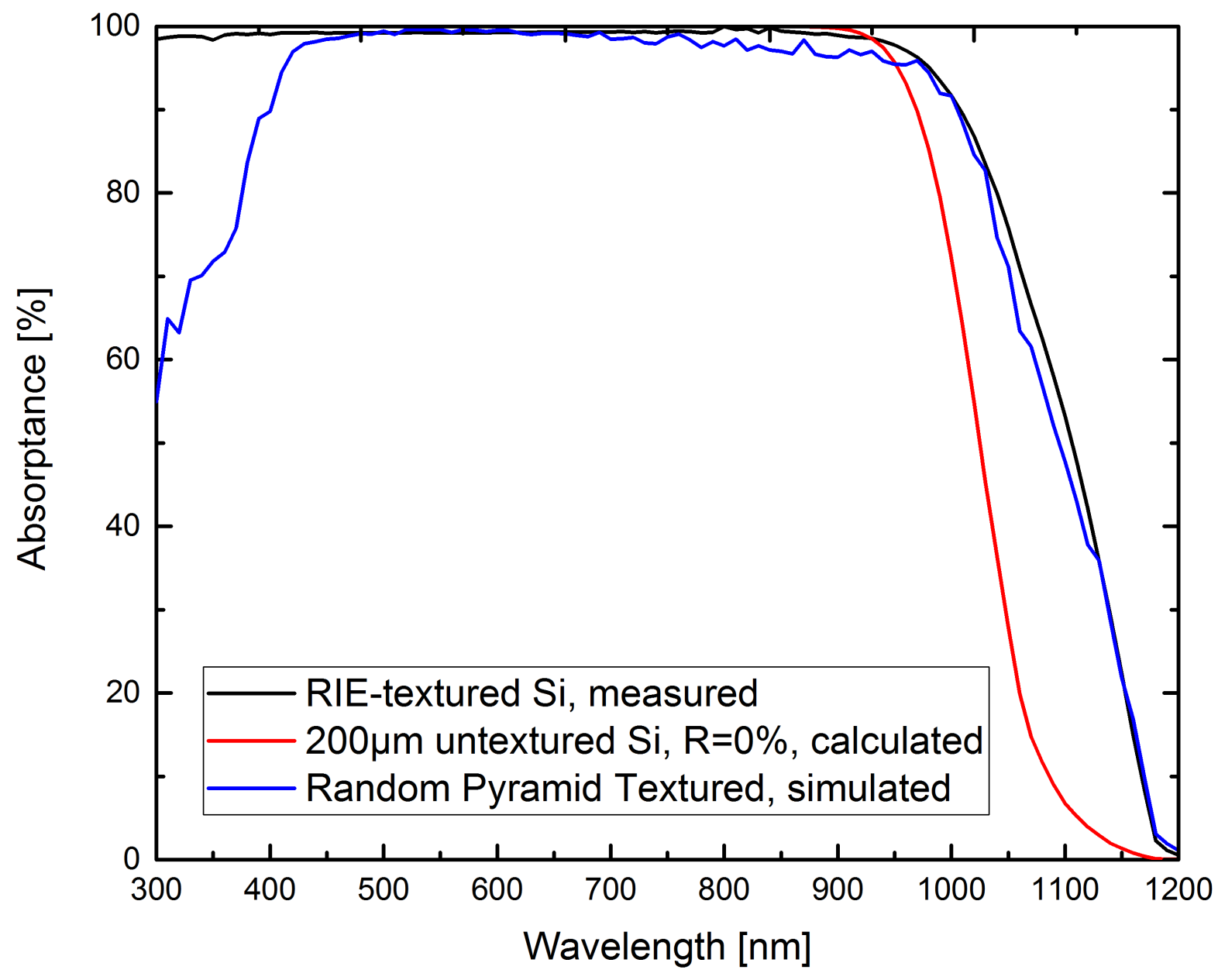

Figure 3: Light absorptance of the black Si surface before cell processing as function of the wavelength. The absorptance was measured with a center-mount inside an integrating sphere. The incident angle of the light source deviated $8^{\circ}$ from normal incidence due to the geometry of the measurement setup. 


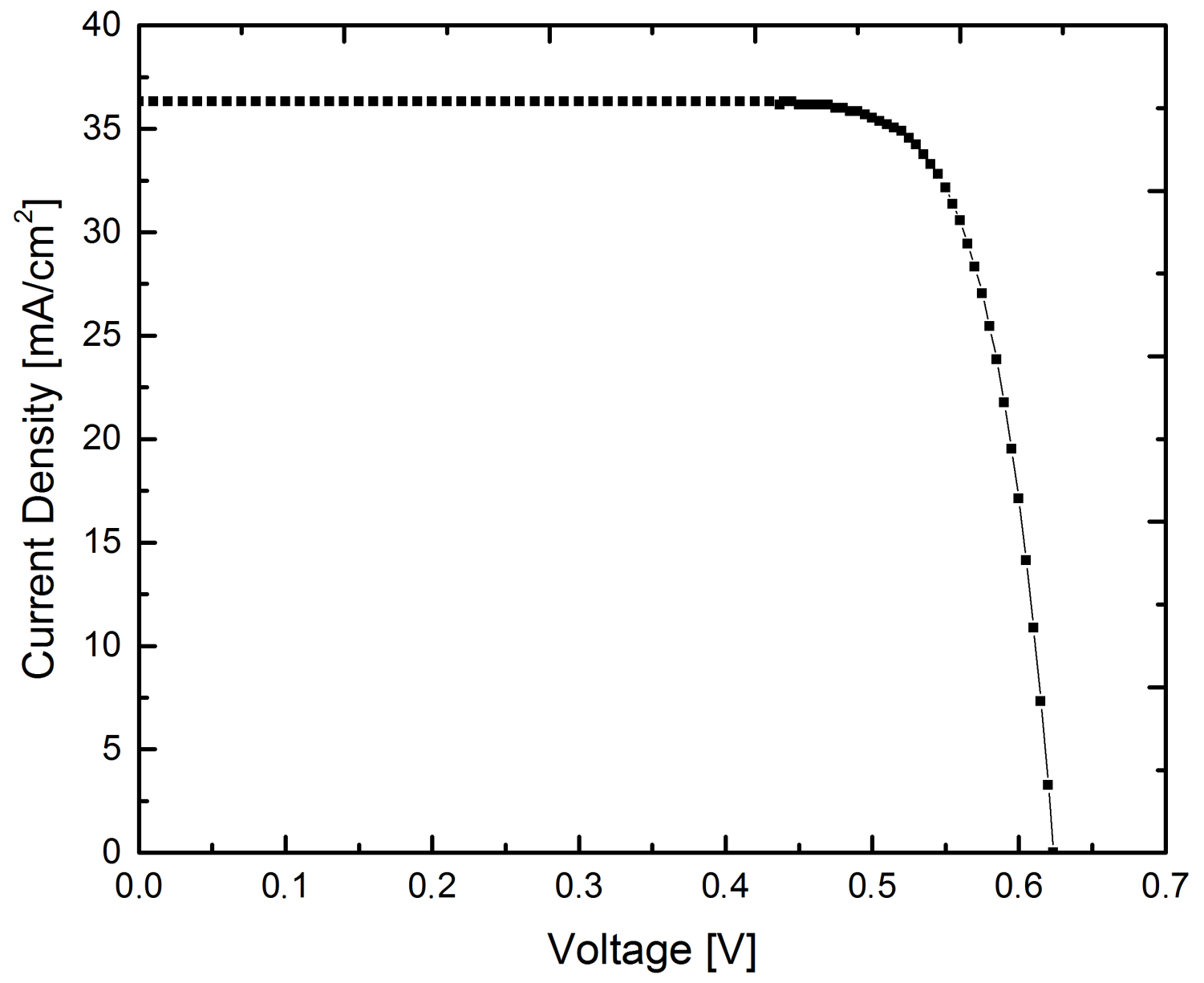

Figure 4: Current density-voltage characteristic of the best black Si LDSE solar cell under 1 sun illumination $\left(1000 \mathrm{~W} / \mathrm{m}^{2}\right.$, AM1.5G). The short-circuit current density, $J_{\mathrm{SC}}$, is 36.3 $\mathrm{mA} / \mathrm{cm}^{2}$ and open-circuit voltage, $V_{\mathrm{OC}}$, is $624 \mathrm{mV}$. The power conversion efficiency is $18.1 \%$ and the fill factor, $\mathrm{FF}$, is $80.1 \%$ 

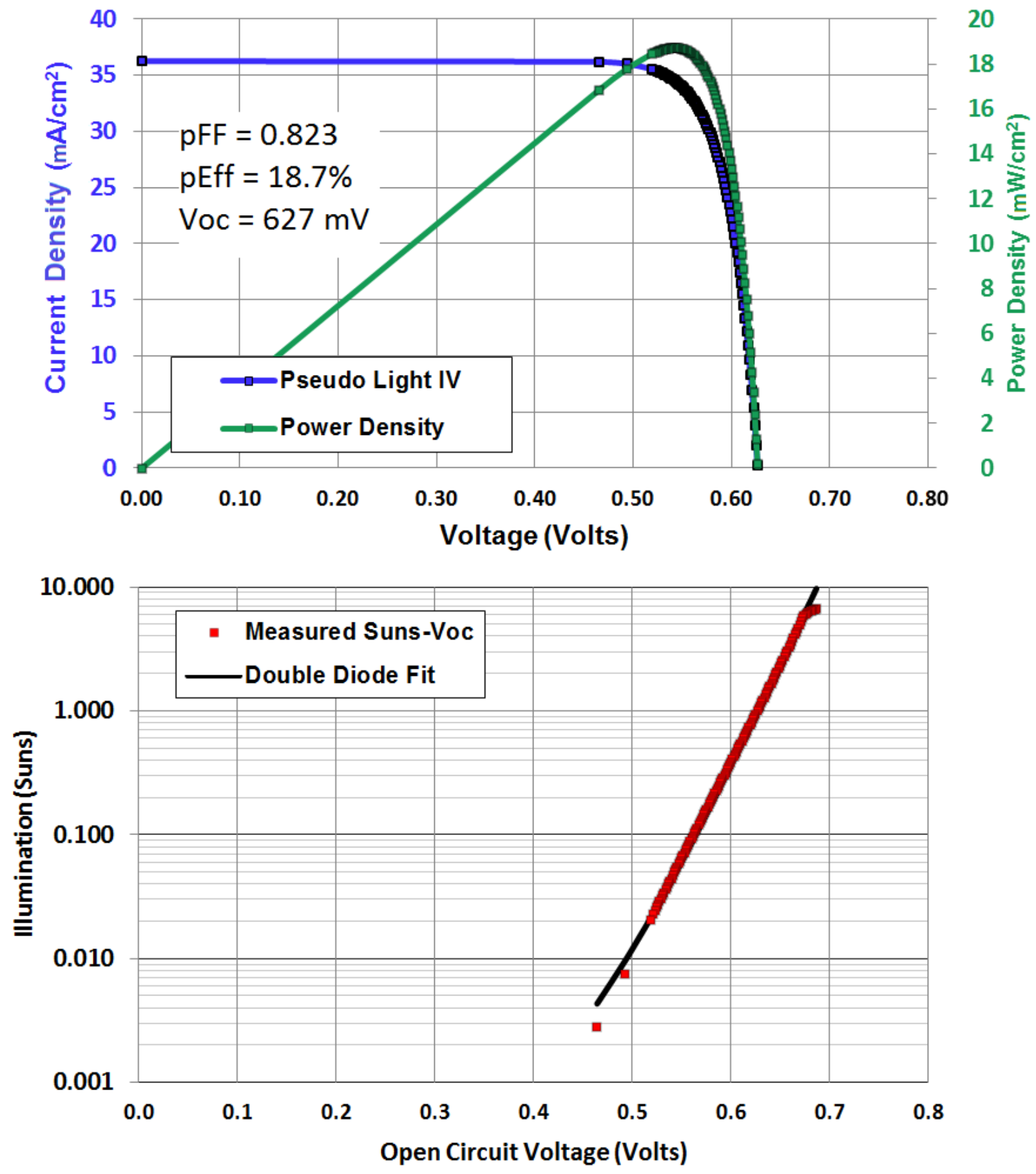

23

Figure 5: Result of the Pseudo Light J-V (top) and (middle) Suns-V $\mathrm{V}_{\text {OC }}$ measurement of the best black Si LDSE cell processed at a laser speed of $3 \mathrm{~m} / \mathrm{s}$. The measurement shows a pseudo fill factor, $\mathrm{pFF}$, of $82.3 \%$ and a pseudo efficiency, $\mathrm{pEff}$, of $18.7 \%$ without the effect of series resistance. 


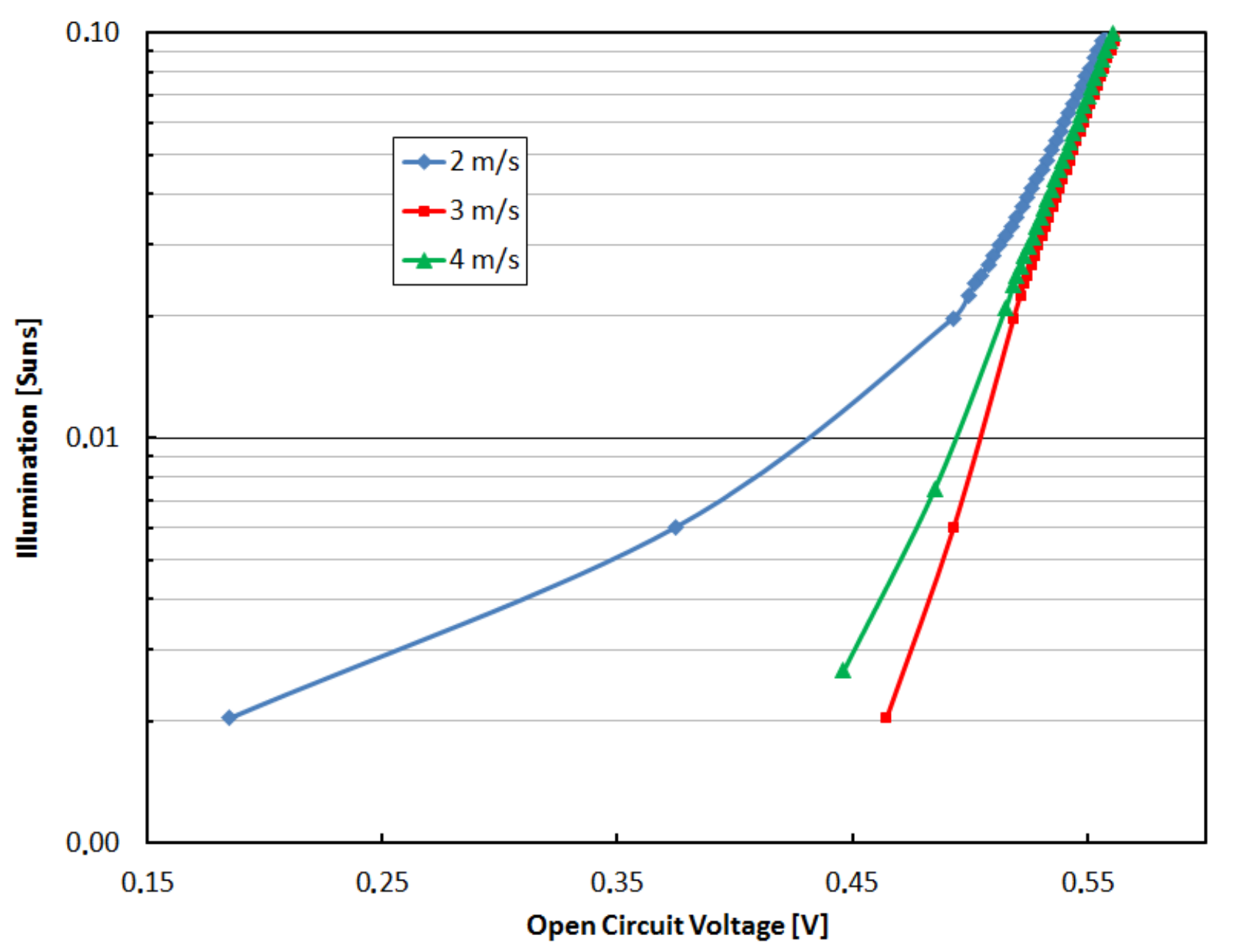

Figure 6: Suns- $\mathrm{V}_{\mathrm{OC}}$ measurement at low injection of three black Si LDSE cells processed at laser speeds of 2,3 and $4 \mathrm{~m} / \mathrm{s}$, respectively. 


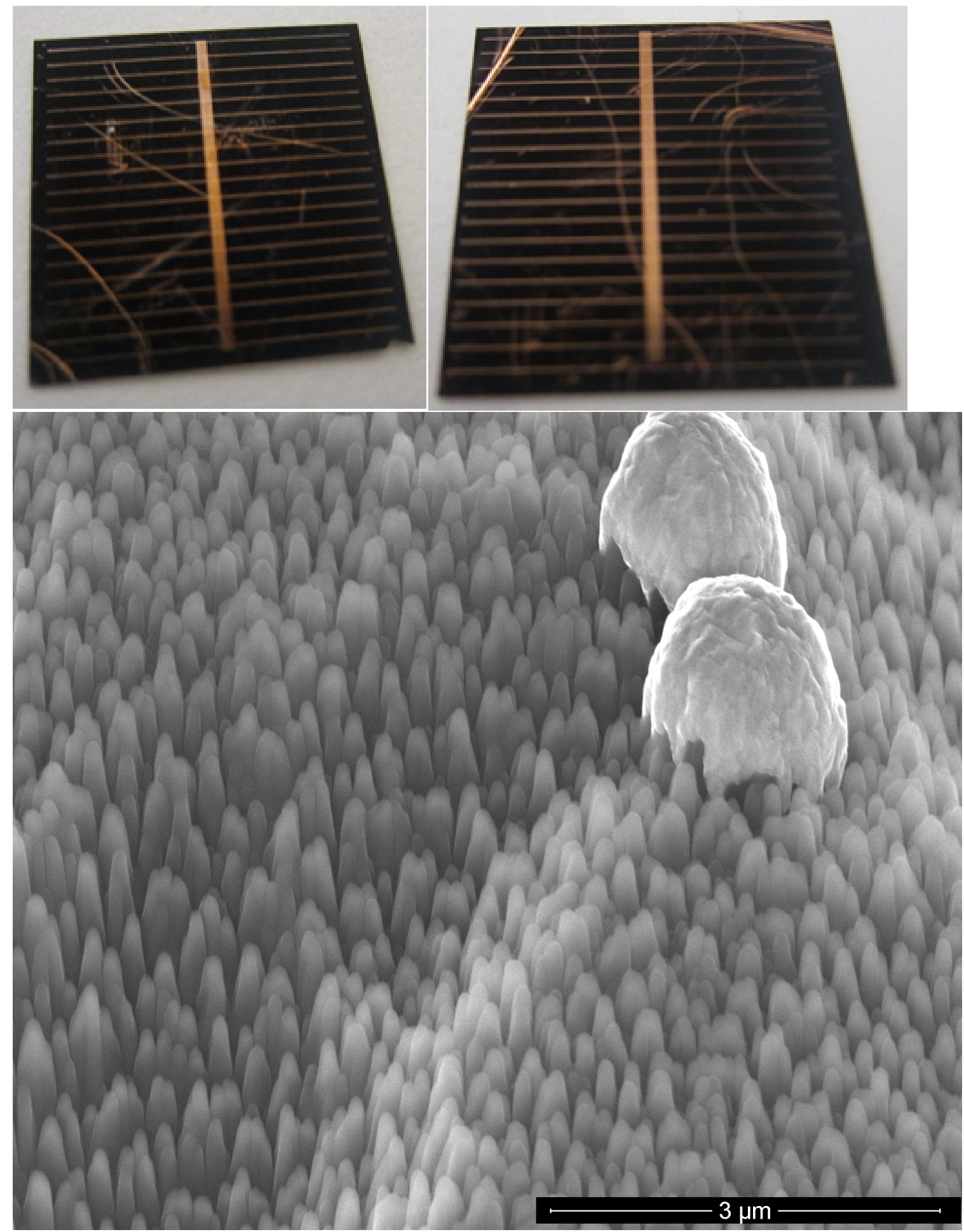

Figure 7: (Top) Photographs of 2 of the fin 25 black Si LDSE solar cells. The images show significant spurious plating of $\mathrm{Ni} / \mathrm{Cu}$ and scratches in the front surface. (Bottom) SEM-image at $52^{\circ}$ tilt of the RIE-textured surface of the final black Si LDSE solar cell surface. The SEM-image also shows examples of spuriously plated $\mathrm{Ni} / \mathrm{Cu}$. 


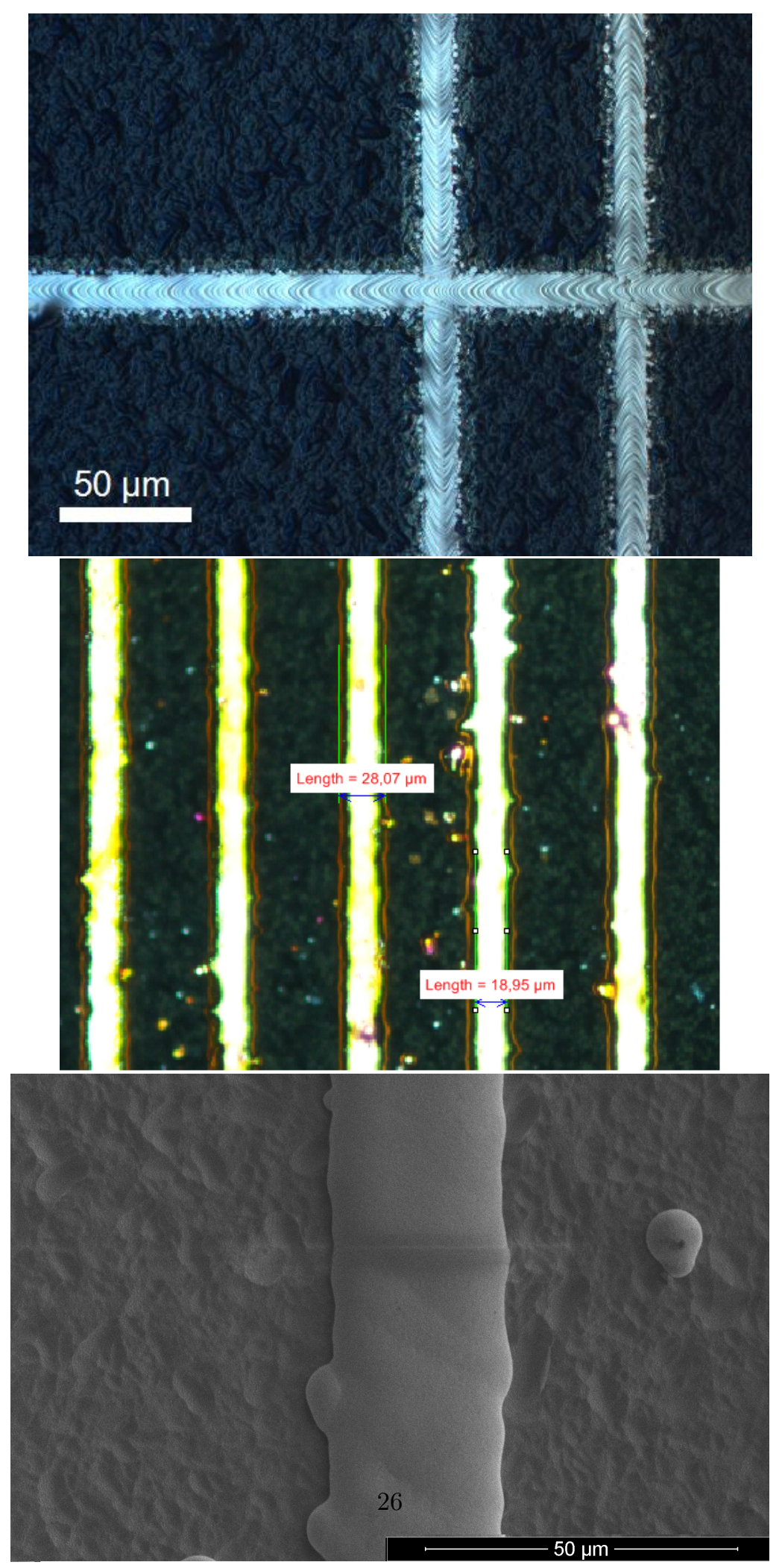

Figure 8: (Top) Optical microscope image of the laser-doped lines on the black Si front surface before $\mathrm{Ni} / \mathrm{Cu}$-plating. (Middle) Optical microscope image showing the width of the $\mathrm{Ni} / \mathrm{Cu}$-plated metal lines in this case from the busbar. (Bottom) Top-view SEM-image of a $\mathrm{Ni} / \mathrm{Cu}$-plated metal line. 


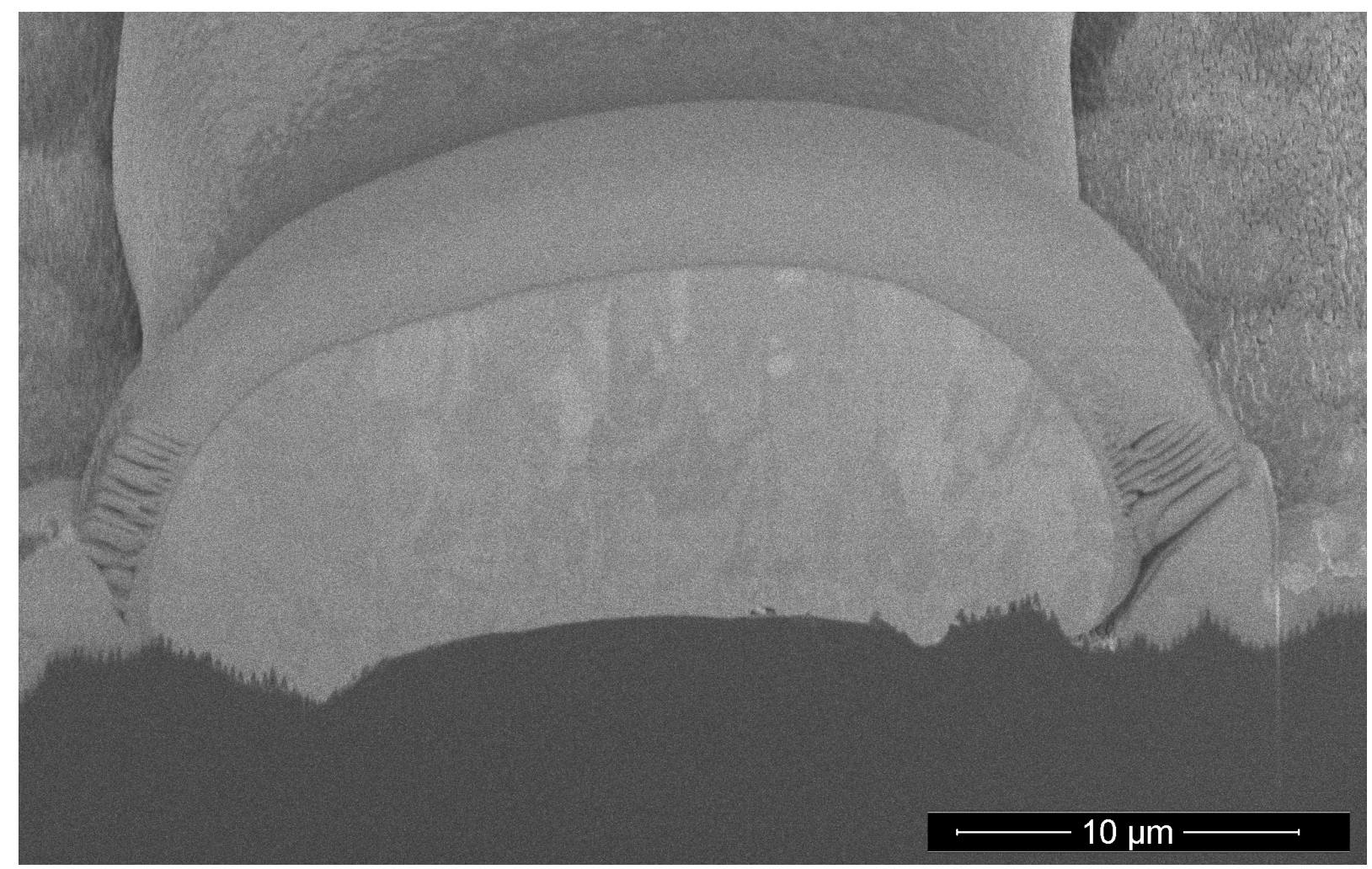

Figure 9: SEM-image at $52^{\circ}$ tilt showing the cross-section of a $\mathrm{Ni} / \mathrm{Cu}$-plated metal line. The cross-section was defined by a Focused Ion Beam (FIB). The plated metal line is $\sim 30 \mu \mathrm{m}$ wide and $\sim 10 \mu \mathrm{m}$ in height. The layer seen on top of the Ni/Cu-line is $\mathrm{Pt}$ used solely for sample protection during FIB cutting. Note that the black silicon nanostructures are visible at the edges of the plated $\mathrm{Ni} / \mathrm{Cu}$ line. 


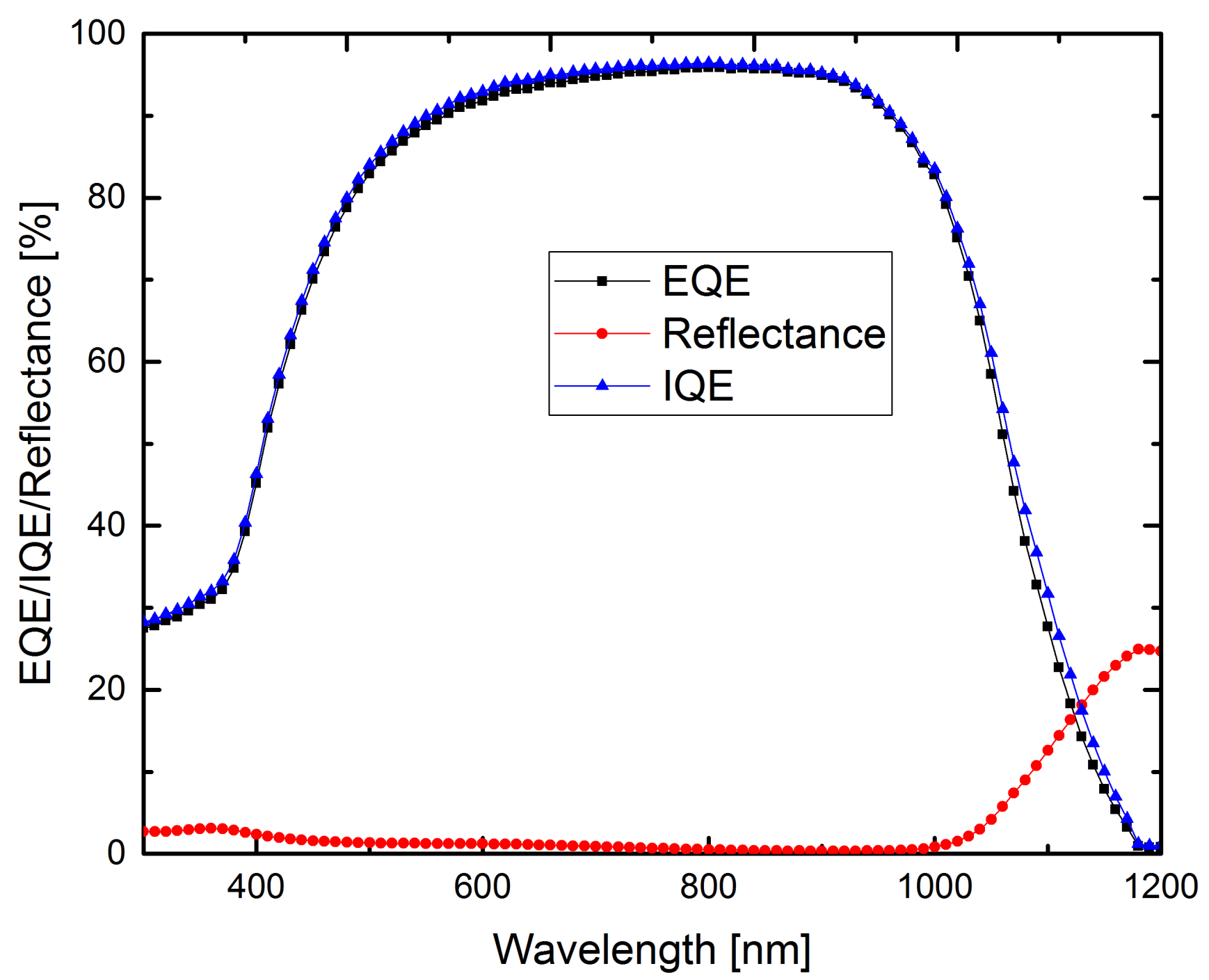

Figure 10: External and Internal Quantum Efficiency and total reflectance as function of wavelength of the $18.1 \%$ black Si LDSE solar cell. The reflectance data are for RIE-textured Si with AR-coating before any further processing. The IQE is calculated based on the measured EQE and reflectance of the surface measured before laser and plating processes. EQE was measured without any bias light. 


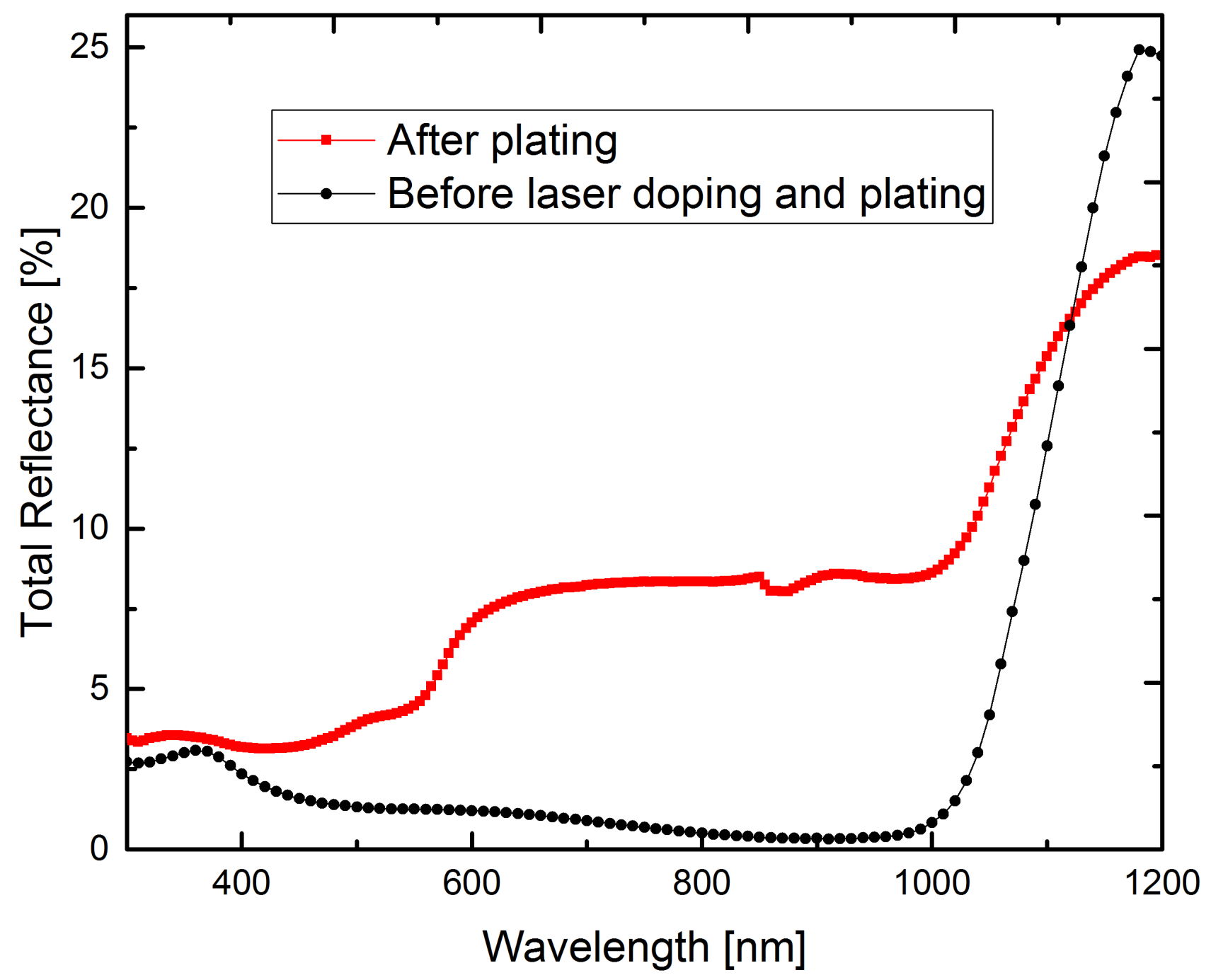

Figure 11: Total reflectance of the RIE-textured Si surface with AR-coating before and after laser doping and Ni/Cu-plating, respectively, as function of wavelength. The beam spot size of the light source was $\sim 2 \mathrm{~cm}$ in diameter and covered the majority of the cell area including the busbar and metal fingers. 


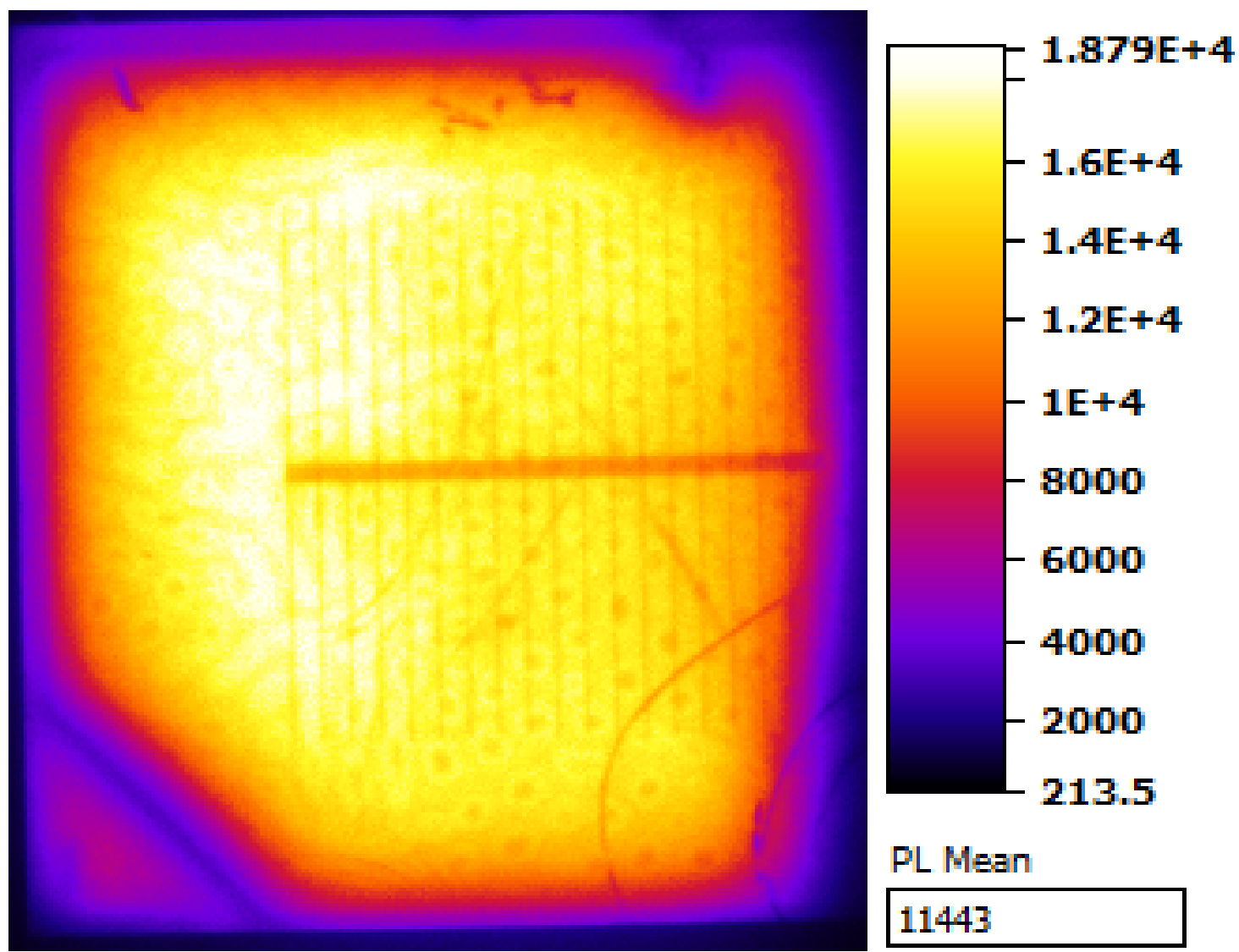

Figure 12: Open-circuit Photoluminescence (PL) image of the cell after Ni plating and sintering, but before $\mathrm{Cu}$ plating and edge isolation. The feature in the bottom left corner of the image is due to the shape of the screen-printed $\mathrm{Al}$ on the rear. 


\begin{tabular}{|c|c|c|c|c|c|c|}
\hline Author & Texturing & $\begin{array}{l}\text { Eff. } \\
{[\%]}\end{array}$ & $\begin{array}{l}\mathbf{J}_{\mathrm{SC}} \\
{\left[\mathrm{mA} / \mathrm{cm}^{2}\right]}\end{array}$ & $\begin{array}{l}\mathbf{V}_{\mathrm{OC}} \\
{[\mathrm{V}]} \\
\end{array}$ & $\begin{array}{l}\mathbf{F F} \\
{[\%]}\end{array}$ & $\begin{array}{l}\text { Cell Type } \\
\text { Passivation, Cell Area }\end{array}$ \\
\hline This work & RIE & 18.1 & 36.3 & 0.624 & 80.1 & $\begin{array}{l}\mathrm{CZ} \text { LDSE } \\
\mathrm{SiN}_{x}, 6.25 \mathrm{~cm}^{2}\end{array}$ \\
\hline Repo et al. [17] & RIE & 18.7 & 39.2 & 0.632 & 75.8 & $\begin{array}{l}\text { FZ PERL } \\
\mathrm{ALD} \mathrm{Al}_{2} \mathrm{O}_{3}, 4 \mathrm{~cm}^{2}\end{array}$ \\
\hline Yoo et al. 20 & RIE & 16.7 & 36.8 & 0.617 & 76.0 & $\begin{array}{l}\text { CZ Screen-printed } \\
\mathrm{SiN}_{x}, 156.25 \mathrm{~cm}^{2}\end{array}$ \\
\hline Oh et al. 19. & MACE* & 18.2 & 36.5 & 0.628 & 79.6 & $\begin{array}{l}\text { FZ, evaporated contacts } \\
\text { Thermal } \mathrm{SiO}_{2}, 0.8081 \mathrm{~cm}^{2}\end{array}$ \\
\hline Wang et al. 21] & MACE* & 18.2 & 41.3 & 0.598 & 75.1 & $\begin{array}{l}\text { CZ, evaporated contacts } \\
\mathrm{ALD} \mathrm{Al}_{2} \mathrm{O}_{3}, 0.92 \mathrm{~cm}^{2}\end{array}$ \\
\hline Savin et al. [18] & RIE & 22.1 & 42.2 & 0.665 & 78.7 & $\begin{array}{l}\text { FZ, IBC } \\
\mathrm{ALD} \mathrm{Al}_{2} \mathrm{O}_{3}, 78.5 \mathrm{~cm}^{2} \text { (4") }\end{array}$ \\
\hline
\end{tabular}

Table 2: Selected black silicon solar cell results reported in literature. The table shows power conversion efficiency, $\mathrm{J}_{\mathrm{SC}}, \mathrm{V}_{\mathrm{OC}}$, fill factor and type of solar cell and Si substrate. For further details about the cell type we refer to the references. *Metal-Assisted Chemical Etching (MACE). 